\title{
A View from Agricultural and Applied Economics
}

\author{
Mark Henry*
}

\begin{abstract}
Is regional science too focused on abstract models, theorizing, and methodology with weak links to policy and practice? Not from the perspective of the land grant university, where many applied economists with a regional science interest reside. The job of these applied economists it, in part, to translate the models and methods into tools for the use in understanding regional development processes and for undertaking policy analysis at the regional level.
\end{abstract}

Pleskovic (1996) identifies "the problem" with regional science and "the solution" to the problem in two passages: the problem,"...the field's preoccupation with abstract models, theorizing, and methodology; the weakness of its links to policy and practice; and the lack of in-depth analysis of specific areas..." (p. 1); and the solution, "In a stimulating assessment of the history, status and future of regional science, Isserman (1995) calls for a reorientation of the field toward applied regional science" (p. 1).

Andy Isserman has taken his message seriously. In his recent moves from the Regional Research Institute at West Virginia University to the Public Policy Institute in San Francisco to the Department of Agricultural Economics at the University of Illinois, he has revealed a preference to get academic work out to people who make policy and implement programs. Certainly, most regional scientists based in departments of agricultural and applied economics would be sympathetic to both Isserman's migration pattern and to his solution to the hypothesized problem. But is there a real relevancy problem for regional science? Again, borrowing from Isserman, "It's Obvious, It's Wrong, and Anyway They Said It Years Ago" (Isserman 1996, p. 37).

\section{It's Obvious}

Debates over the merits of theory versus application are longstanding in the agricultural economics community. Some with an applied bent became discouraged by the emphasis on mathematical rigor (relevance to the cynics) in the leading journal, the American Journal of Agricultural Economics $(A J A E)$. This resulted in two new publications by the same people who publish the $A J A E$-Choices and The Keview of Agricultural Economics. In these newer outlets, the case study and policy implications of research (often using the $A J A E$ level of rigor but translated

*Professor, Faculty of Economic Development, Department of Agricultural and Applied Economics, Clemson University, Clemson, SC. 
for the general audience) are examined in a serious dialogue of what the research has to offer to policy makers.

Closer to the regional science camp, Niles Hansen (1995, p. 337), in his unique style of unpretentious clarity, agrees that there is a tension between theory and practice in regional science-but again, what else is new? Don't worry; be happy. Regional science may not have gained the disciplinary stature of its fathers' dreams, but it has attracted many accomplished scholars from economics, geography, planning, and other disciplines. And, practitioners have benefited directly from working with regional science scholars-often when they don their consulting hats. One example I recall is a 1970 s vintage consulting report for the TVA on the impacts of new nuclear power plants by Walter Isard. Knowing how a straightforward economic impact study should be done-the nuts and bolts of proper accounting procedures and the limitations of the methods used (like regional $\mathrm{IO}$ )-comes to practitioners from working with or reading the applied work of regional science scholars. Contemporary research by regional scientists at the Regional Economics Analysis Laboratory/University of Illinois is a good example of leading regional scientists developing new and better ways to construct regional models for use by practitioners in the Chicago region. It's my guess that it is not unusual for theoretically oriented regional scientists to also do applied work when the incentives are sufficient and then spin off knowledge to practitioners along the way.

Indirectly, applied regional science literature has educated practitioners on the use of regional science methods for impact analysis and theory to help them understand regional dyriamics. But this literature often evolves from scholars and their students who are in the business of developing theory and quantitative methods, testing hypotheses, and doing in-depth case studies.

On the other hand, few would suggest that practitioners-like bureaucrats in state and local departments of economic development-would embrace the New Economic Geography (NEG). The field of spatial economics, à la Krugman $(1991,1995,1996)$, is not accessible to practitioners despite the intuitive style of the Ohlin lectures (Krugman 1991). But regional scientists (and some mainstream economists) have been inspired by the NEG-and the associated entree to leading economics journals like the Journal of Political Economy (JPE), the American Economic Review $(A E R)$, and the Quarterly Journal of Economics (QJE)-to improve our understanding of empirical regularities across space. Examples of the postKrugman-era harvest of new ideas from academics can be found in Ed Glaeser's work with Ellison (Ellison and Glaeser 1997) and others (Dumais, Ellison, and Glaeser 1998), and in Audretsch and Feldman (1996). These scholars look at increasing returns from the vantage point of spillovers and nonrandom distributions of manufacturing activities. New ways are developed to measure geographical concentration that are consistent with microeconomic foundations of producer behavior (Ellison and Glaeser 1997). They find that geographic concentration across four-digit manufacturing industries is pervasive in the U.S.-but only some 
of these industries are as "strongly" clustered as Krugman's example of the carpet industry in Dalton, Georgia (Krugman 1996). Still, from an applied regional science perspective, clusters seem to matter as a force in regional development. In terms of policy, practitioners become aware of these regional forces of economic change and focus state and local development efforts to develop self-sustaining clusters. See Barkley and Henry (1997) for some examples and cautionary notes. While this scenario from theory to applied regional science to policy is a bit overdrawn, it is a familiar model of research and extension to those of us in the Land Grant System. So, in this context, it is hard to see what the "big deal" is among regional scientists who worry about pure theory versus application.

In contrast, it is unlikely that Krugman and the theoreticians have an interest in publishing in the Economic Development Quarterly-it's too case study oriented with little discussion of behavioral models with microeconomic foundations. Ok. No problem. Be happy. The role of the academic scribbler and the power of his or her ideas matter more than practitioners recognize as, I hope, is illustrated by the Krugman/clusters scenario.

Moreover, some theoreticians in geography (see Sheppard 1998, Plummer 1998, and Puga 1998 for recent discussion) suggest that the Krugman and related neoclassical models are too restrictive as they ignore the history and geography that are region specific. Others call for in-depth case examinations with new notions of a "region in a global economy where politics and economics are interwoven with a substrata of culture... where markets prevail over plans and where transformation continues to override static notions of structure" (Berry 1995, p. 302). Roger Bolton (1998) calls for a new investigation of the economic meaning and consequences of "the sense of place." Of course, these are signs of a healthy debate on the identification of fundamental forces shaping the future of regions. Again, this literature is not accessible to the practitioner. However, it is the job of the applied regional scientist-like those in departments of agricultural and applied economics-to translate the theoretical results into the nuts and bolts of regional development analysis and to evaluate the efficacy of local policy alternatives in the light provided by the theorist. But should regional science swallow the Isserman prescription-become more applied or perish? I think not. Regional scientists (housed in many disciplinary homes) need to develop theory, challenge assumptions, and rework the model implications. Maureen Kilkenny is a good example of current laborers in this field and she is housed in an agricultural economics/economics department at Iowa State. Thus, my second contention is:

\section{It's Wrong}

Isserman (1995) laments the opportunities lost by regional scientists to be engaged in analysis that begins with policy relevance, a niche that has been filled by the fifty or so policy analysis schools around the U.S. (the LBJ school at the University of Texas, for example). Isserman does suggest that the Southern Regional Science Association (SRSA) "based" regional scientists and agricultural econo- 
mists with a rural development or natural resources area of interest are less guilty of being "policy irrelevant" than most members of the Regional Science Association International (RSAI). The work of Tom Johnson, a leading agricultural economist and SRSA-based regional scientist, and the Rural Policy Research Institute (RUPRI) at the University of Missouri are good examples of the land grant university (LGU) building models and "information systems" for local practitioners to address "real problems." This sort of research/extension effort has a long in the LGUs. A declining farm clientele and a real fear that many rural towns left to confront a dwindling farm base will simply wither away (see Beneke 1998), have spawned efforts by some LGUs to reach out to a new clientele with a focus on economic development practitioners.

So, if one looks at efforts like those at Missouri, the future is bright for applied regional science. The demand for information and economic intelligence is likely to grow as local leaders and practitioners become more aware of what the universities have to offer in solving their problems of economic development. And it is likely to be the regional science "types" who are most serious about the proper use of methods and the development of new analytical tools to help solve these problems. Still, there are problems in applied regional science as pressures grow to do "something" even if the data are old and methods are of questionable validity. Some RUPRI models are so deeply embedded in spreadsheets that seri= ous tests of the reliability of the information-parameter estimates, prediction accuracy, etc:-are largely unknown to the outside academic reviewer. Of course, the role of the applied regional scientist is to worry about this.

The "pure" regional scientists who worry about increasing returns models of monopolistic competition and how they can explain spatial patterns of economic activity (e.g., Kilkenny 1998) will eventually have their day with practitioners, as the academic scribbler filtering process works its mysterious way to the "real world." Others, like Harvey Miller (1998), think and write about pure issues concerning how to measure geographical accessibility. In a long succession of papers Luc Anselin confronts "pure" issues of how to estimate parameters when confronted with "real world" spatial data that exhibits spatial dependence and autocorrelation. Obviously, the advances in accessibility measures and spatial econometrics reported in the Journal of Regional Science or Regional Science and Urban Economics will be directly useful to the applied regional scientist and indirectly to the practitioners.

Is regional science "lost in space" along those infamous homogeneous plains with stochastic decision trees? Not to my mind. The theoreticians are on a roll, thanks in large part to the "Krugman effect." One can gauge the magnitude of this effect by glancing through the contents of the AER, JPE, and QJE for six years before and after 1991(Krugman's Geography and Trade publication date.) The number of "regional" articles has taken off after 1991 in these leading theoryoriented economics journals.

And the applied regional scientists are doing important work on a wide range of policy issues both in the U.S. and Europe. The 1997 European Regional 
Science Association meeting in Rome was peppered with discussions of European Union and transition economy policy issues; this was both expected and welcomed. Similar observations can be made about recent meetings of the RSAI, SRSA, and Western Regional Science Association that I have attended over the past five years. One session in Cincinnati is particularly apt. A panel on business incentives included the ex-Mayor of Cincinnati, Maryann Feldman from Johns Hopkins University, and Bernard Weinstein from the University of North Texas. Here, practitioners and regional scientists debated the merits of business incentives as an economic development tool. Closer to home for me, my colleagues, Dan Rainey and Jim Hite, were labeled "pointy headed" professors by South Carolina Governor David Beasley's staff when they projected that current tax incentives were likely to bleed the state treasury for years to come. They were subsequently vindicated in the press, and even the former State Director of Revenue began echoing the same message that Rainey and Hite delivered. I suppose most attendees of this SRSA meeting have similar stories they could tell of applied regional science making a difference.

So is Andy right about the need to shift regional science to a more "applied" focus? I think it's already there, which brings me to the final point:

\section{They Said It Years Ago}

In economics, Leontief, in his 1971 Presidential Address to the American Economics Association, scorned theory without fact without much impact on the discipline of economics. Similarly, pitting theory versus practice in regional science seems unlikely to yield a new discipline or better practice. It's obvious that we need both better analytical tools and policy relevance in tandem. Some would argue that Computable General Equilibrium (CGE) models are a great advance over Input-Output (IO). Others, like Berry (1995), suggest that even CGE is likely to be of little value in a global society where "interest group politics" and "market institutions" prevail. So the great methodological debates swirling around logical positivism and the empiricists are still with us. While the academic soul searching over the future of regional science as a "theoretical" or "applied" school is not exactly a debate over scientific method, it may be useful to recall that in the late 19th century, the German Historical School tried to beat back the onslaught of the marginal revolution of Jevons, Menger, and Walras in economics. Schumpeter (1954, p. 815), commenting on this Methodenstriet, drew the following conclusions:

The first thing to be observed about all controversies between scientific parties is the large amount of mutual understanding that enters into them...men frequently have but an inadequate notion of what the other fellow really worries about... Hence a great part of the fighting is directed against positions which are indeed hostile fortresses in the imaginations of the warrior but which on inspection turn out to be harmless windmills. 
Secondly, this situation is made worse by the fact that methodological clashes often are clashes of temperaments and of intellectual bents...things will be more difficult where neither party can boast of spectacular successes that conciliate and impress. Moreover, every decent workman loves his work. And this alone, for some of us, implies dislike for other "methods" in a perfectly irrational and impulsive way.

Third, we must never forget that genuine schools are sociological realities--living beings...Victory and conquest, defeat and loss of ground, are in themselves values for such schools and part of their very existence. They will try to appropriate labels that are considered to honorific...both parties laid claim to such epithets as "empiric," "realistic," "modern," "exact," and to affix derogatory labels-"speculative," "futile," "subordinate,"-to the work of the enemy. All this gives scope to personal vanities, interests, and propensities to fight that may...count for more than any real issues -in fact to the point of obliterating the real issues.

Is there a danger of obliterating the real issues in regional science by pursuing a school of "applied regional science" at the expense of a school of "pure regional science," in which scholars are focused on abstract models, theorizing, and methodology with weak links to policy and practice and lacking in-depth analysis of specific areas? I don't think so. There may be few departments of regional science, but active regional science meetings and scholarship will continue as long as there are real issues to resolve, and there seems to be no shortage of these real issues-applied and theoretical.

\section{REFERENCES}

Audretsch, David B., and M.P. Feldman. "R\&D Spillovers and the Geography of Innovation and Production." American Economic Review 86 (1996), 630-640.

Barkley, David L., and Mark S. Henry. "Rural Industrial Development: To Cluster or Not to Cluster?" Review of Agricultural Economics 19 (1997), 308-325.

Beneke, Raymond R. "Progress Comes Dressed in Strange Clothing." Choices (First Quarter) (1998), 42-44.

Berry, Brian J.L. "Whither Regional Science?" International Regional Science Review 17 (1995), 297-306.

Bolton, Roger. "Place Prosperity vs. People Prosperity Revisited-An Old Issue with a New Angle." Urban Studies 29 (1992), 185-203.

Dumais, Guy, Glenn Ellison, and Edward Glaeser. "A Dynamic Analysis of the Geographic Concentration of Industry." Paper presented at the Conference on Analytical Economic Geography and Regional Change, Storrs, CT, March 23-24, 1998. Abstract available at: www.ucc.uconn.edu/ $\sim$ wwwgeog/nsfmeet.html. 
Ellison, Glenn, and Edward Glaeser. "Geographic Concentration in U.S. Manufacturing Industries: A Dartboard Approach." Journal of Political Economy 105 (1997), 889-927.

Hansen, Niles. "Regional Science, Regional Policy, and the 'New' Regional Economics: Future Possibilities in Historical Perspective." International Regional Science Review 17 (1995), 337-342.

Isserman, Andrew M. "The History, Status, and Future of Regional Science: An American Perspective." International Regional Science Review 17 (1995), 249296.

. "It's Obvious, It's Wrong, and Anyway They Said It Years Ago?' Paul Krugman on Large Cities." International Regional Science Review 19 (1996), $37-48$.

Kilkenny, Maureen. "Necessity, Variety and Timing." Paper presented at the Conference on Analytical Economic Geography and Regional Change, Storrs, CT, March 23-24, 1998. Abstract available at: www.ucc.uconn.edu/ $\sim$ wwwgeog/nsfmeet.html.

Krugman, Paul. Geography and Trade. Cambridge, MA: MIT Press, 1991.

. Development, Geography and Economic Theory. Cambridge, MA: MIT Press, 1995.

"Urban Concentration: The Role of Increasing Returns and Transport Costs." International Regional Science Review 19 (1996), 5-30.

Leontief, Wassily. "Theoretical Assumptions and Nonobserved Facts." American Economic Review 61 (1971), 1-7.

Miller, Harvey. "Measuring Space-Time Accessibility Benefits Within Transportation Networks." Paper presented at the Conference on Analytical Economic Geography and Regional Change, Storrs, CT, March 23-24, 1998. Abstract available at: www.ucc.uconn.edu/ wwwgeog/nsfmeet.html.

Pleskovic, Boris P. "Introduction to the Special Issue on Regional Science and Development." International Regional Science Review 19 (1996), 1-4.

Plummer, Paul. "Capital Accumulation, Economic Restructuring, and NonEquilibrium Regional Growth Dynamics." Paper presented at the Conference on Analytical Economic Geography and Regional Change, Storrs, CT, March 23-24, 1998. Abstract available at: www.ucc.uconn.edu/ $\sim$ wwwgeog/nsfmeet.html.

Puga, Diego. "The Rise and Fall of Regional Inequalities." Paper presented the Conference on Analytical Economic Geography and Regional Change, Storrs, CT, March 23-24, 1998. Abstract available at: www.ucc.uconn.edu/ wwwgeog/nsfmeet.html.

Schumpeter, J.A. History of Economic Analysis. Oxford: Oxford University Press, 1954.

Sheppard, Eric. "The Complexity of Geographical Competition." Paper presented at the Conference on Analytical Economic Geography and Regional Change, Storrs, CT, March 23-24, 1998. Abstract available at: www.ucc.uconn.edu/ wwwgeog/nsfmeet.html. 
